\title{
The Family Housing Sector in Urban Ghana: Exploring the Dynamics of Tenure Arrangements and the Nature of Family Support Networks
}

\author{
Ransford A. Acheampong \\ Department of Land Economy, University of Cambridge, 19 Silver Street, Cambridge CB3 9EP \\ UK; E-Mail: raa49@cam.ac.uk \\ Journal: International Development Planning Review
}

Date Accepted: 21-Sep-2015.

\begin{abstract}
In urban West Africa, living rent-free in family-owned houses is common among the low-income population. Drawing on research from Kumasi, Ghana, this paper explores the dynamics of this non-market tenure, in terms of the nature of family support networks/reciprocity and how collective ownership and multiple-occupancy arrangements affect dwelling conditions and the rights derived by tenants. The practice of extending support among members of the kinsfolk, underpinned by traditional values of reciprocity, were found to be stable within the present-day family house. However, the younger generation of residents expressed the view that to support members of the kinsfolk was over-burdensome given the prevailing economic hardship and their limited resource capacity. While tenure security across generations was not guaranteed for accessby-privilege residents, shared-ownership meant that for the majority of residents, the family house could not serve as a productive asset from which wealth could be released in response to economic shocks. Most households crowded in single rooms, shared strained housing facilities and lacked privacy. These dynamics could potentially turn preferences away from rent-free family housing in the near future, and thus generate the need for rental housing in the city. Affordable rental housing development would be required to adequately meet the emerging need.
\end{abstract}

Key words: Rent-free, compound house, extended family, support networks, Kumasi

\section{Introduction}

Neo-liberal economic policies pursued under Structural Adjustment and the accompanying public sector cuts, among other things, have resulted in limited state involvement in housing provision in Ghana, since the 1980s (Arku, 2009; Konadu-Agyemang, 2001; Yeboah, 2005). With the ever growing mismatch between housing need and housing supply, as well as the rising housing 
unaffordability relative to incomes particularly in the owner-occupier sector, many low-income households find shelter in the rent-free housing sector (Acheampong and Anokye, 2015).

In urban Ghana, two main types of rent-free tenancy arrangements exist. One type of rentfree occupancy common in peri-urban areas, occurs under what is known locally as 'caretaker' arrangement. Under this tenancy arrangement, owners of uncompleted houses engage a caretaker to look after the house, building materials and keep the site tidy; in return, the caretaker does not pay rent (Gough and Yankson, 2011). Another type of rent-free housing common in Ghana are those provided by the extended family system, known locally as Abusuafie. Under this tenure arrangement, independent households belonging to an extended family live together in a traditional compound house, bequeathed from one generation to the other without paying rent (Tipple et al., 1997). In most West African societies, including Ghana, the provision of free housing constitutes one of the major ways by which richer members of the extended family extend support to the kinsfolk. As Tipple et al., (1997) and Korboe (1992) note, within the Ghanaian context, the traditional family system 'imposed' some form of cultural obligations on wealthy members to house extended family members who could not afford to provide their own shelter.

In spite of the important role of the rent-free family housing sector in housing supply, a survey through the literature shows that in Ghana, few studies (e.g. Korboe, 1992; Tipple, 1997) have examined the dynamics of this non-market housing sector. These studies concluded that the family housing sector provides housing safety-net and mitigates the social costs of poverty and old-age. These conclusions are predicated on the traditional function of the extended family as an instrument of support to its members across generations either out of altruistic or egoistic motives (Aboderin, 2004b; Cremer et al., 1992; Cox and Fafchamps, 2007). 
Over the two and a half decades since the first foundational work was conducted, Ghanaian society has undergone changes in the prevailing social, economic, political and cultural systems that shape the dynamics of family relations in general and the family housing sector in particular. Firstly, recent empirical evidence from across Sub-Saharan Africa indicates that traditional family bonds are becoming weak, resulting in the terminal decline of associated values of support and reciprocity. The decline in familial support is seen partly as a general consequence of rapid urbanization, modernization, increasing commercialization, and the growing view of the extended family as 'parasitic' among the current generation (Aboderin, 2004a; Devereux, 2001; Korboe, 1992). Moreover, there is a declining resource capacity on the part of the young generation to provide material support to extended family relations (Aboderin, 2004a). Consequently, society is increasingly becoming individualistic with normative expectation emphasising self-reliance emerging and becoming established (Aboderin, 2004a). The literature would therefore benefit from new evidence providing insight into how the processes of modernization, urbanization and the accompanying changing socio-economic and political conditions, have shaped the traditional values of mutual support and reciprocity, within the present-day family compound house.

Secondly, as a family-owned property, the right of ownership and use of the family house is often shared among all relevant members of the kinsfolk whether they live in the property or not. An equally important question therefore, is how such collective-ownership and multioccupancy arrangements in the family house affect living conditions, right of use of the property and security of tenure across generations. The available literature however, does not provide definitive answers to these questions regarding occupancy dynamics in the family housing sector.

Against this backdrop, this paper examines the present-time dynamics of the rent-free family housing sector from the Ghanaian context. Given that family housing constitutes one of the 
key support systems of the extended family, the study explores how the processes of modernization, urbanization and the changing socio-economic and political conditions have shaped the traditional values of mutual support and reciprocity within the family compound house. The study also examines the different tenure arrangements within the family housing sector and how collective ownership and multiple-occupancy arrangements determine rights, privileges and the general dwelling conditions within the family house.

The rest of the paper follows in three sections. In section two, a conceptual framework for the study is presented followed by a discussion of the methodology adopted in section three. In the penultimate section, the results of field data are presented and discussed. The paper ends with a concluding discussion in section five.

\section{Conceptual Framework}

\subsection{The family house within the context of changing socio-economic conditions}

Traditionally, extended family-based support networks have been a key resource in extending assistance to members in the absence of formal welfare systems (Aboderin, 2004a; Cox and Fafchamps, 2007; Langevang, 2008; Rhoads, 1985). The sustained capacity of the family housing sector to provide accommodation for members across generations, therefore depends largely on the resilience of the extended family system and associated support networks over time. There is however, a growing body of literature that indicate that traditional family bonds are increasingly becoming weak whilst the associated support networks are gradually disappearing in rapidly urbanizing Ghana (Aboderin, 2004a; Langevang, 2008) and in other African countries (Devereux, 2000; Foster, 2000). The terminal decline of traditional kinship ties in urban Africa can be 
understood from two main theoretical positions - Modernization and Political Economy perspectives.

Modernization theory is broadly concerned with the historical processes of transformation in social, economic and political systems of society and how these shape social organization, attitudes, behaviour and values (Fangjun, 2009; Peng, 2009; Jiafeng, 2009). Central to modernization theory are the processes of urbanization and industrialization, and how these processes affect social relations at the city, neighbourhood and family scales. To this end, the city is equated with modernity; rational, instrumental, impersonal and voluntary forms of social interactions typifies the modern urban life (Tonkiss, 2005; Wirth 1995; Goode, 1970; Logan et al., 1998).

As a consequence of rising values of individualism, secularism and an emphasis on emotional bonds within the nuclear family, customary filial obligations and norms tend to weaken with obligations towards members of the kinsfolk no longer compelled by the force of custom but by discretion (Aboderin, 2004a; Beck et. al., 2003; Burgess, 1960; Cowgill, 1974). The breakdown of the traditional extended family and the emergence of the 'isolated nuclear' family eventually, results in gradual decline in the flow of material support among members of the extended family (Aboderin, 2004b).

Whereas modernization theory focuses on the transition from 'traditional' to 'modern', political economy enquires into the origins, character and distribution of wealth in the development process. It addresses the principal questions of who gets what in the development process, why and with what consequences (Castree, 2010). Within the framework of the political economy perspective, the growing decline in kinship ties and associated support networks over time are seen 
as the residual outcomes of what the reality of economic development has been for many developing countries including Ghana.

Most countries in Sub-Sahara Africa, including Ghana have since the early 1980s experienced Structural adjustment programmes (SAP) as a means to restructuring their economies by balancing national budgets, liberalizing trade and improving macro-economic stability (Hilson and Potter, 2005; Lall et. al., 1994; Rothchild, 1991; Gibbon, 1995; Simon et al., 1995). The pursuit of neo-liberal economic reforms have not yielded all positive results. Instead, the failure of free markets have manifested in economic stagnation, destruction of social capital, low earning levels, increasing cost of living and pervasive poverty (Anyanwu, 2013; Bracking, 2003; Fields, 2011; Salami, 2013). In Ghana, although the actual impacts of SAP are still debated, there is a general consensus in the literature that austerity policies associated with neo-liberal reforms have perpetuated poverty and contributed to persistent economic hardship, unemployment and uncertainty for the larger mass of the population (Briggs and Yeboah, 2001; Clark, 1999; Langevang and Gough, 2009).

As a consequence of limited resource capacity resulting from economic constraints (Aboderin, 2004a; Bengtson et al., 1997; Moser, 1998), increasing commercialization (Foster, 2000) and growing perception of possessions as personal property rather than belonging to the extended family (Devereux, 1999), the traditional practice of transfers from wealthier members to poorer folks of the extended family no longer become sustainable. Recent evidence from Accra, Ghana's capital have shown that the ideals of traditional values of extended family support and reciprocity are not being fulfilled due to limited resource capacity particular on the youth, the majority of whom struggle to find employment (see for example, Aboderin, 2004a ; Langevang, 2008; Langevang and Gough, 2009). 


\subsection{The Family House as a Productive Asset: Opportunities and Constrains}

At the household level, housing constitutes an important tool for income generation, wealth accumulation and poverty reduction in most developing countries (see for e.g. Forrest \& Murie, 2013; Gough \& Kellett, 2000; Sinai, 1998; Verrest, 2007). Moser's 'asset-vulnerability framework' identifies housing as an important productive asset without which individuals and households could be made poor while increasing their vulnerability against economic shocks (Moser 1998).

Generally, households enjoy a set of rights and advantages depending on their housing tenure arrangements. Owner-occupiers enjoy the benefit of tenure security, the right to adapt the building to particular tastes and the advantage of using the house as a productive asset by renting part or whole of it and/or borrowing against the value of the house (Franz, 2006; Huan and Mahoney, 2002). In the case of the family house, ownership arrangements and associated rights, privileges and tenure security are far more complex. As a family property, the right of ownership and use of the property is often shared among all relevant members of the kinsfolk whether they live in the property or not. However, much is not known about how such collective-ownership and multi-occupancy arrangements affect the right of use of the property. Given the complex ownership system and the many prevailing interests, can households living rent-free count on the family house as a productive asset?

From the preceding discussions, it is evident that the family housing sector is a complex one with its dynamics affected by the interplay among several complex global and local processes. Historically, the traditional family housing has, constituted a major subsidiary support system of the extended family system in Ghana. Weakening family bonds resulting from modernization, and 
limited economic opportunities would potentially impact tenure arrangement and dwelling dynamics and traditional values of mutual help and reciprocity Also, collective ownership and multi-occupancy arrangements could affect living conditions, tenure security across generations and right of use of the property and by beneficiary households Together, these would potentially, have implications for the prospect of the family housing sector in sustainably providing housing for low-income families.

\section{Method}

The city of Kumasi, located within the Kumasi Metropolis in Ghana was purposively selected as case study area for this study. Previous studies have established the predominance of family-owned traditional compound houses in the historical core of the city.

Four inner-city neighbourhoods namely; Bantama, Asafo, Adum-Kejetia and FanteNewtown constituted the locations of empirical enquiry within the city. Whereas the Adum-Kejetia area has traditionally functioned as the Central Business District (CBD) of the wider metropolis, over the years, the CBD is expanding into the adjoining neighbourhoods of Bantama, Asafo and Fante-Newtown.

It is currently estimated that some 24 percent of all households in the Kumasi Metropolis live rent-free (Acheampong, 2013). The available data, however, does not disaggregate into rentfree accommodation obtained through caretaker arrangements and those provided by the extended family in traditional compound houses at the metropolitan and neighbourhood levels. This meant that a known sampling frame from which a more representative sample size could be determined probabilistically was not available. In view of this practical constraint and on the basis of the 
researchers resources (i.e. financial and personnel), a total of 100 households $^{1}$ living rent-free in the family housing sector in the four inner-city neighbourhoods comprised the study sample. A total of 30 interviews were conducted in Asafo; 30 in Fante-Newtown; 25 in Bantama and 15 in the Adum/Kejetia neighbourhoods ${ }^{2}$.

A structured but open ended interview guide was used to elicit quantitative and detailed qualitative responses from the selected households. Interview questions were grouped under four main thematic areas determined at the design stage of the survey instrument in line with the research objectives. These were [1] background information on respondents and occupancy characteristics; [2] bundle of rights and privileges conferred on occupants; [3] tenure security across generations; and [4] support networks within the family house.

Interviews were conducted in February 2015 over a period of four weeks by 10 field assistants (including the author). The interviews involved face-to-face interaction sessions with adult members of the 100 households selected. Each interview session lasted between one and a half and two hours. Since traditional compound houses in the study area typically have more than one independent household occupants, one household was interviewed in each house visited. Thus, the 100 households interviewed came from 100 separate family-owned compound houses. For each household selected, the adult member, who was directly related to the extended family that owns the house they occupied, was interviewed. It is worth clarifying that these were not

\footnotetext{
${ }^{1}$ A household in this study follows the official definition adopted by the Ghana Statistical Service as comprising a person or a group of persons, who lived together in the same house or compound and share the same house-keeping arrangements.

2 The author's local knowledge of these inner neighborhoods, having lived in the city for over 20 years, was particularly useful in identifying these family houses providing rent-free accommodation in the four neighborhoods selected. The sample distribution was not based on the number of households living rent-free in each neighbourhood, instead, they represent the number of households that could be reached, who were willing to participate in the research.
} 
necessarily heads of the household and the study did not establish whether these respondents selfidentified as heads of their respective households.

With the consent of the respondents, 20 of the interviews were digitally recorded. The remaining 80 did not agree to being digitally recorded so their responses were recorded manually. All interviews proceeded on a prior agreement between the interviewers and interviewees that the responses elicited would be anonymised. After each day's interview session, while the interview session remained fresh in the minds of the interviewers, the responses gathered were transcribed by each of the interviewers and reviewed by the researcher to ensure accuracy, validity and consistency of transcripts.

The interview transcripts were collated and organised by questions and grouped under the four main pre-set themes for each of the four case-study neighbourhoods. For the purposes of accurate extraction of the data and to ensure anonymity, each respondent was identified by a numerical code assigned in the sequence of 1 to 100 in accordance with the order in which they were interviewed. The approach adopted allowed for the identification of consistencies and differences and for systematic synthesis, interpretation and presentation of results.

The qualitative responses were manually analysed whilst the background quantitative variables were processed using statistical analysis software-SPSS. From the quantitative data, descriptive statistics of mainly percentages and measures of central tendencies were derived. Anonymised verbatim quotations were also selected from respondents. The selection of direct quotations depended on whether the spoken words of respondents were needed to provide explanation, deepen understanding or to provide evidence to support deduction made from the responses. In order to provide the relevant context in the presentation and discussion of results, 
sections based on detailed qualitative responses elicited during the survey, begin with a summary of the nature of the questions posed to the respondents.

\section{Results and Discussion}

\subsection{Characteristics of Respondents}

The survey respondents were aged between 18 and 72 years with an average age of 34 years (SD $=10.8$ ). More than half of all household representatives interviewed had lived rent-free in the family house for over 20 years (Mean=23years; Maximum= 62 years; $\mathrm{SD}=16.1$ ). This means that for the majority of respondents, the family house has provided shelter for the most part of their lives, with some of them born in the family house where they currently live.

Tables 1 and 2 provide a summary of background socio-economic information about the survey respondents. Levels of educational attainment were generally low among the representatives of rent-free households interviewed. The majority of respondents were either educated up to Junior high school (16 percent) or Senior high school (45 percent). Nearly a quarter of rent-free occupants interviewed had acquired tertiary level education.

able 1: Characteristics of respondents

\begin{tabular}{l|l}
\hline Variable & Percentage \\
\hline a. Gender & \\
Male & 59 \\
Female & 41 \\
Sample Size & 100 \\
\hline b. Levels of Educational Attainment & \\
Below Junior High School & 16 \\
Junior High School & 45 \\
Senior High School & 13 \\
Vocational/technical & 2 \\
Tertiary & 24 \\
Sample Size & 100 \\
\hline c. Employment &
\end{tabular}




\begin{tabular}{l|l} 
Employed & 75 \\
Unemployed & 15 \\
Retired & 10 \\
Sample Size & 100 \\
\hline
\end{tabular}

Table 2: Respondents' Monthly Incomes

\begin{tabular}{l|l|l}
\hline \multirow{2}{*}{ Income measure } & \multicolumn{2}{|c}{ Value } \\
\cline { 2 - 3 } & GH $\boldsymbol{\text { US\$ Equivalent }}$ \\
\hline $25^{\text {th }}$ percentile & 500 & 116.55 \\
50 percentile & 800 & 186.48 \\
75 percentile & 1200 & 279.72 \\
Minimum & 300 & 69.93 \\
Maximum & 2500 & 582.75 \\
Std. Deviation & 506.56 & 118.08 \\
\hline
\end{tabular}

About 75 percent of the survey respondents were in employment while 10 percent were in retirement. Out of the number employed, 80 percent worked in the sales and service sector within the informal economy, and were engaged mainly in petty trading activities located close to their places of residence in historical core of the city. The remaining 20 percent were all formal sector workers including teachers and nurses and bankers. Typical of most informal economy workers involved in petty trading in Ghana, monthly earnings among respondents were generally low with a lower quartile income of GHф500 and average monthly earning of GHф800.

\subsection{Tenure Types, Tenure Security and other Bundle of Rights Granted}

Tenure arrangement in the traditional family housing sector is complex than is often assumed. In addition to the two broad typologies identified by Korboe, (1992), two different forms of tenure were identified by this study. These typologies were defined based on information elicited on ownership of the properties and the relationship between the owners, the survey respondents and other members of the extended family living in the house. Below, the reasons for living in the 
family, tenure security and associated bundle of rights granted are differentiated along the four main typology of tenure identified.

\section{The resident-landlord}

Resident-landlords were individual owners of the property who have granted members of the extended lineage access to room(s) in the house to live rent-free. The property becomes a family house by virtue of it being occupied by the owner's extended family relatives but all rights of use and ownership rest with the resident landlord. This class hereafter referred to as 'resident-landlord' constituted about 5 percent of tenure arrangement. As the owner of the property, tenure security is guaranteed for the resident-landlord and his or her household. The resident-landlord has the right to give all or part of the property to other tenants under rental and/or rent-free arrangements and to release wealth accumulated in the house either by selling it or using it as collateral security when borrowing. The resident-landlord also possesses the right to bequeath the property by will to his/her immediate household (i.e. children and partner) or to the external family relatives of the matrilineal lineage in line with customary law.

\section{Shared-ownership-by-inheritance}

The second category of rent-free tenants, hereafter referred to as shared-ownership-byinheritance,' gained access through inheritance often specified in a legally binding testament or will. About one-fifth of respondents interviewed fell under this tenure arrangement. The primary reason for occupying the property was to demonstrate appreciation and respect by fulfilling the will of the benefactor to inherit and take care of the property. Living rent-free was therefore not the immediate motive but rather, a derived benefit. 
This tenure type can be derived in one of two ways. First, among the Akan ethnic group who dominate in the city of Kumasi and owns most of these properties, inheritance and determination of descent is traced through the female line (i.e. matrilineal).This means that family members belonging to the female line of the original owner of the property, who are not necessarily his/her children but nephews, could become shared owners as the property is bequeathed across generations. Second, the original owner may first bequeath the property to his/her children either by will or through the Interstate Succession Act, $1985^{3}$, after which the property may be passed down through the female line (i.e. daughter(s) of the original owner) in line with customary law. The response of one male respondent below lends credence to this route to shared-ownership:

I don't consider myself the owner of this house...although my father left it for us when he died, there are five of us - four males and one female; our sister takes primary ownership in line with our matrilineal system of inheritance.

A number of rights accompany shared-ownership-by-inheritance. Tenure security is guaranteed for the individual members of the lineage who have jointly inherited the family house. That of the shared-owners' immediate household however, in principle terminates when they die, and sometimes on the dissolution of marriage. There is no guarantee that the deceased shared-owners' nuclear family would be allowed to continue to live in the family house as such decision is subject to the discretion of the one who inherits the property. Thus, by living in family house, widows and their children bear the risk of being evicted from the family house anytime — and the respondents cited many instances where this had happened. As one married female respondent recounted:

Living in the family house has its downsides; there is uncertainty regarding how the family would treat you and the children when their relative to whom you're married dies or in times of divorce... Not too long ago, the wife and children of a deceased, in that compound house located just three

\footnotetext{
${ }^{3}$ The Interstate Succession Act, 1985 (PNDC Law 111), is applied in Ghana, in instances where people die leaving assets but do not make a will. Under this law, the compulsory beneficiaries of the deceased's assets are the surviving spouse and/or children.
} 
houses away, on the other side of the street, were asked to find accommodation elsewhere immediately after the funeral rites.... Although the family gave them time to move, I thought that was inconvenient and very unfair.

Shared-owners are allowed to only rent out part of the house allocated to them if they choose not to occupy it. The right to release wealth from the property through other means are however completely curtailed as custom forbid them to either sell it or enter into financial transactions using whole or part of the property as collateral. As one shared-owner indicated:

I cannot sell my part of the house. It is clearly defined in the will that under no circumstance should part or the entire house be sold... I cannot use my part of this house as collateral for a loan neither can I pass it on as inheritance to my spouse and children... The house is an inheritance and will forever remain the property of my maternal generation.

\section{Access-by-privilege}

The third class of occupants, hereafter referred to as 'access-by-privilege' gained access by virtue of being members of the family. The right of occupancy is granted to this group either by the 'shared-ownership-by-inheritance' or 'resident-landlord' class. Access-by-privilege tenancy therefore does not bestow any direct ownership rights onto occupants. About 70 percent of respondents lived under the access-by privilege tenure arrangement.

The reasons for living in the family house for this category of tenants included the benefit of living rent-free and closer to extended family relations. Some had moved in so as to take care of their relatives (parents and grandparents in old age) whilst looking after the property. In the case of young adult-single-person households, living rent-free in the family house was considered a suitable tenancy arrangement at early stages of adulthood, with the hope of transitioning to other forms of tenure sometime in the future. This could be when they are able to build or rent their own accommodation or in response to life-cycle changes such as getting married and having children. As one such young adult respondent indicated: 
I am a young adult, growing up...I work in the city [Kumasi] so I didn't find the need to rent when the family house was readily available for me to occupy. I will probably leave when I get married.

Tenants under this category, do not possess any rights per say but enjoy the benefit of living in the family house rent-free. Tenure security is uncertain as continued occupancy is subject to the approval of their living benefactors, and terminates on the death of their benefactor with no guarantee of being renewed. Like the immediate family members of a deceased shared-owner, access-by-privilege tenants could be evicted anytime from the property. This is evidenced by a quote from one such rent-free tenant that "My tenancy is secured for as long as my grandfather lives...When he dies, the decision will be in the hands of the one who will inherit it".

On the approval of their benefactor (s), access-by-privilege occupants could conduct homebased economic activities inside the house subject to the availability of extra rooms or within the immediate vicinity of the family house. Apart from this, their tenure agreements completely curtails all rights or opportunities of using the house as a productive asset either by renting out the part allocated to them or using it as collateral. As one of the respondents indicated:

I will make no monetary gain in renting out my room; the proceeds will go to the person who gave the room to me. If for any reason I choose not to live here anymore, I have no stake in any decision pertaining to the vacant room.

\section{Shared-owners-in-waiting}

A fourth derivative arrangement, hereafter referred to as 'shared-owners-in-waiting' was identified. Shared-owners-in-waiting were adult descendants having their own separate households and living in the same house with their parents or grandparents who are the owners of the house (i.e. resident-landlord). Thus, although they do not possess any ownership rights, they would eventually become shared-owners when the property is passed on to them as inheritance. 'Shared-owners-in-waiting' constituted about 5 percent of all types of rent-free living arrangements in the family housing sector. This category of rent-free tenants have secured tenancy 
but do not have or exercise ownership rights until they inherit the property either individually or jointly. Once they inherit the property, they assume all the accompanying ownership rights depending on whether they become shared-owners or resident-landlords.

In sum, within the family compound or tenement house, it is impossible to separate decisions regarding the use of part of the property allocated to occupants from the whole property. Tenure security is not guaranteed across generations for the majority of residents who live under access-by-privilege arrangements. Under collective ownership arrangements, several property rights of the individual occupants are severely curtailed. Although these constraints ensure that the houses are preserved for use across generations, they present a number of disadvantages too. It is generally impossible for tenants, irrespective of their status, to release wealth from part or the entire property through for example, collateral arrangements or outright sale. Limited wealth and constraints on borrowing against the property value could constrain occupants' ability to respond to short-term shocks in the absence of support from extended family relations. This also discourages investment in the house and regular maintenance by these occupants, and may partly explain why the majority of family houses in the study area, by the author's observation, were in physical deterioration.

4.3 Occupancy Characteristics, access to facilities and Privacy issues within the Family House As shown in table 3 , up to 8 separate households on the average would be found living in the same family house with 5 individuals constituting each household. Thus, in a typical family compound house, there could be up to 40 members of the kinfolk living in the same house. Moreover, a typical family compound house could have up to 13 habitable rooms. More than half of all families interviewed occupied a single room while one-third occupied two rooms in the family house. 
Similar occupancy characteristics were reported by the 2010 Population and Housing Census which shown that some 64 percent of all households in the Kumasi metropolis occupy single rooms mostly in compound houses.

Table 3: Occupancy Characteristics in the Family House

\begin{tabular}{|c|c|c|c|c|}
\hline \multirow{2}{*}{ Occupancy Characteristics } & \multicolumn{4}{|c|}{ Descriptive statistics } \\
\hline & Minimum & Maximum & Mean & $\begin{array}{c}\text { Std. } \\
\text { Deviation }\end{array}$ \\
\hline Family size & 1 & 18 & 5 & 3.4 \\
\hline Total number of separate households living in the house & 1 & 30 & 8 & 4.8 \\
\hline Number of rooms occupied by household in the house & 1 & 5 & 1.6 & 0.9 \\
\hline Total number of rooms in the house & 1 & 40 & 13 & 6.2 \\
\hline
\end{tabular}

The ratio of family size to the number of rooms occupied shows that the majority of households were crowded in single rooms in the rent-free family housing sector. The prevailing room occupancy rates exceed the overcrowding threshold of two persons per room recommended by the UN-Habitat (see UN-Habitat, 2011). As the survey found, the existing room sizes were considered small by occupants to adequately accommodate all members of the family as well as their personal belongings; no opportunity existed for expansion or addition of rooms in the majority of the cases as plots had been fully built. Moreover, the study found that all facilities inside the family house were shared. In most cases, all occupants depended on one bathroom, one kitchen and one toilet facility. In fact, for most of these houses, it was not until recently that some of the rooms initially meant for habitation were converted into bathrooms and toilets. The use of communal sanitary facilities located outside the house was common among households living in the family housing sector in all the four neighbourhoods surveyed.

In addition to the above dwelling characteristics, the survey elicited residents' assessment of the general living conditions in the family house in terms of privacy issues and relationship with other members of extended family with whom they lived together. A significant share of 
households interviewed felt that living with extended family relations in the same house meant they did not have enough privacy in handling sensitive personal matters. Couples with children felt that the family house was not the ideal environment for raising a family in line with personal principles and values given all the unsolicited intrusions and possible influences from other members of the extended family. As one respondent living with his wife and children in the family house indicated:

One's privacy is not guaranteed living with such large number of extended family relations...my siblings often come to my room to have a word with me and my wife is not very happy and comfortable about it; there is basically no privacy here...I think living outside the family house, but closer to the CBD would be good for me and my [nuclear] family.

Besides the privacy concerns raised, occupants also reported frequent petty and sometimes protracted squabbles among extend family relations as one major disadvantage associated with living in the family house. Quarrels often would arise from sharing responsibilities for cleaning common areas in the house. Others thought they were just the result of feelings of envy and jealousy from other members. The narrative of one household representative interviewed who appeared quite frustrated by the situation is captured as follows:

Quarrels resulting from disagreements among members are quite common in this house. Some folks are always fighting with my wife; there is no peace of mind...I see there's disunity among occupants... preferably everyone should be living in his or her own building or at least in a rented accommodation outside the family house.

In an attempt to demarcate a personal space and reclaim some of their lost privacy, a good number of the households had enclosed hitherto open verandas extending across the front of their rooms with metal railings, wood or sandcrete walls.

In sum, to live in the family house to a larger extent, involved some form of trade-off between non-payments of rent on the one hand and comfort, privacy and access to facilities on the other hand. This tenure type does not appear to be the most beneficial for households when benefits are assessed beyond just affordability to include other normative considerations of decent housing 
that affect personal health and well-being such as reasonable room occupancy levels that reduces over-crowding, privacy, comfort and access to basic facilities. Perhaps, they would be ideal at the early stages of adulthood but transition to more suitable accommodation in response to life-cycle changes would be necessary. However, given the general shortage of decent and affordable housing, housing mobility although necessary, would be beyond the reach of the larger mass of low income households who find accommodation in the rent-free housing sector.

\subsection{Support Networks within the Family House}

This aspect of the survey focused on the nature of support networks and reciprocity within the present-day family compound house. Respondents were asked if they received support (in case or kind) from other relatives in the houses either in the past or present, and if they also benefited from support from other members of the kinsfolk. In addition, respondents were asked if they felt their nuclear families lived independently of other families or they could always count on the support of other relatives in the house in times of need.

A synthesis of responses revealed that support networks existed and were found to have remained resilient over time within the 21 st century family compound house. The majority of the respondents indicated giving and receiving material support from extended family relations in both the past and present. Material support exchanges within the family included direct cash transfers for personal up keep, payment of school fees of younger members of the lineage as well as the sharing of meals. Non-material support exchanges included taking care of relatives in old age, taking care of the children of relatives in their absence, watching over each other's personal belongings and providing emotional support in times of bereavement. 
Only a handful of individuals interviewed indicated that they did not receive any material support from extended family relations within the family house. These were individuals who considered themselves self-reliant and financially capable of meeting their own material needs. Even so, they extended support to other members in times of need. As one of the respondents narrated:

I have not received any support either in cash or kind from relatives inside [this family] house. I am employed and paid monthly, so I am able to earn a living...I have rather helped two of my siblings to establish a shop and even secured loans to enable them undertake retail business in second-hand clothing.

Overall, the resilience of support networks within the family house appears to contrast with the modernization perspective that such support systems would decline with urbanization and the concomitant decline in traditional values and emphasis on individualism and emotional bonds within the nuclear family. Although the majority of the respondents had families of their own (i.e. nuclear families), support was not confined only to members of their immediate families but was extended to other members of the lineage.

Despite the resilience of support systems over time, opinions were sharply divided between the older and younger generations with respect to the ideals of mutual support and reciprocity. As one 62 year old tenant recounted:

Living in the family house with extended family relations has many benefits...people are not selfish like the nuclear family of today; it's only their children they think about. Our ancestors thought about the need for mutual support that's why they built these houses...today we are all enjoying the benefit of living here without paying any rent.

Consistent with the findings of a study by Aboderin, (2004a) that investigated the flow of material support among old and young members of families in Accra, it appears that the older generation of the extended family in this study favoured the traditional ideals of mutual support and reciprocity. On the contrary, the younger generation viewed the extended family members within 
the family house setting as being parasitic and excessively burdensome. As one respondent in his mid-twenties recounted:

It is not easy living in a family house as a young person starting life; there is always pressure on you to help other family members despite not earning so.... when you are unable to help, they tag you as a wicked person, but I simply don't have much to take care of my needs and other peoples' burdens.

In line with the wider political economy literature, the increasing economic hardship, limited economic opportunities and limited resource capacity constrains the younger generations' ability to adequately cater for their own needs and that of their relatives. These experiences of the youth living in the extended family house resonate well with earlier findings in Accra which show a terminal decline in the traditional values and ideals of extended family support and reciprocity particularly among the younger generation (Aboderin, 2004a; Langevang, 2008; Langevang and Gough, 2009).

Moreover, the old practice where individuals, often wealthy members of the extended family paid for maintenance and other utility costs was not found to be pervasive currently as earlier found by Korboe (1992). Instead, each household in most cases, was responsible for paying the costs of utilities (i.e. water, electricity and waste disposal) and routine repairs and maintenance works inside the room(s) allocated to them. Where the entire house is billed together, cost was equitably shared based on each household's consumption. All occupants contributed towards the cost of major maintenance and repair works on the property.

Overall, the family compound house, by bringing members of the lineage together under one big roof, appears to have been successful in preserving and perpetuating traditional values of altruism and reciprocity. Extended family support networks within the family house have remained stable over time implying that occupants, in addition to living rent-free, could count on 
material support from extended family relations. Older members of households emphasised traditional values of sharing and mutual support within the family house as necessary.

In line with the political economy perspective, however, the majority of the respondents indicated that the provision of support to other members was discretionary, subject to their own resource capacity and did not think they were under any obligation to do so. In particular, young adult residents espoused a more modernist perspective and viewed the need to support others as overburdensome and a drain on their already limited resource capacity. It is not exactly clear from the present study how these perspectives would shape preferences towards living rent-free in the family house as opposed to other market tenure arrangements. It is plausible that increasing individualistic inclination of the younger generation could constitute an important determinant of tenure choice decisions of residents in the future. This may also affect the level of support exchanges that would occur among relatives who continue to live in the family house.

\section{Conclusion}

This study has examined the present-time dynamics of the family housing sector- a non-market housing supply channel common in Urban West Africa by drawing on primary data from households living in Kumasi, Ghana.

The study found that traditional values of mutual support and reciprocity have remained resilient over time in the family compound house. Contrary to the modernization thesis which postulates a decline of extended kinship ties and the traditional values of mutual help, the study found that by bringing together members of the kinsfolk under one big roof, the family house has rather preserved not only the ideals but also the practice of material support exchanges among members of the kinsfolk. Even so, the majority of residents believed that the decision to support other members of the extended family was discretionary, subject to ones resource capacity, rather 
than obligatory enforced by traditional customs and values. Consistent with the political economy perspective however, the study found that the youthful generation of residents felt it was unrealistic for them to continue to support other members of the kinsfolk whilst providing for their personal needs, given the prevailing climate of economic hardship and widespread unemployment.

Tenure arrangements were found to be complex, and determined the general living conditions as well as the rights or privileges derived thereof by residents. Living in a family-owned compound house meant that individual families had to forego comfort, privacy and access to decent facilities in exchange for not paying rent. Besides, tenure security was not guaranteed across generations for 'access-by-privilege' occupants who constituted the majority rent-free tenants. Since it is impossible to separate decisions regarding the use of whole or part of the property under shared ownership and multi-occupancy arrangements, several property rights of the individual occupants were severely curtailed. The 'resident-landlord' exercised full ownership rights whilst 'shared-ownership-by-inheritance' residents could only rent-out their part of the property. Tenants under these arrangements were very few. Traditional customs prohibited occupants, irrespective of their tenure arrangements, from releasing wealth from part or the entire property through other means such as collateral arrangements or outright sale of the property. This implies that for the majority of residents, the family house could not be counted on as a productive asset from which they could potentially release wealth, in response to short-term shocks and in the absence of extended family support.

The observed dynamics would potentially impact the nature and prospects of the family housing sector as a key avenue for affordable housing supply. First, it is plausible that the challenges with privacy, overcrowding and access to housing facilities would turn preferences away from the family house to other tenure forms such as renting outside the family house. 
Moreover, the growing view among the younger generation that members of the kinsfolk are a burden on their limited resources, would potentially shape decisions as to whether to live in the family house or not, and determine the level of support exchanges that would occur among relatives who continue to live in the family house in the future. As preferences shift away from the family housing sector, the most likely avenue from which low-income households would seek shelter would be the rental sector. Thus, policy strategies aimed at delivering affordable rental housing at suitable locations would have to be pursued in order to adequately cater for the emerging housing need.

There are a number of ways in which the current research could be extended. As the wider socio-cultural, political and economic contexts within which the extended family system operates undergo changes, it would be useful for future research to examine how the family housing sector in particular, would respond to these trends. The possibility of the sector transitioning from being a non-market channel of low-income housing supply, to providing rental accommodation for families who are not necessarily members of the same kinsfolk warrant further exploration. In addition, the historical core of the major cities in Ghana where family-owned compound houses providing rent-free accommodation are found, have been the primary target of urban redevelopment in recent years. Further research is needed to understand the impacts of the redevelopment process on these family-own compound houses and the low-income families who live in them.

\section{References}

ABODERIN, I. (2004a). Decline in material family support for older people in urban Ghana, Africa: Understanding processes and causes of change. The Journals of Gerontology Series B: Psychological Sciences and Social Sciences, 59(3), SI28-SI 37.

ABODERIN, I. (2004b). Modernisation and ageing theory revisited: Current explanations of recent developing world and historical Western shifts in material family support for older people. Ageing and society, 24(0I), 29-50. 
ACHEAMPONG, R. A., \& ANOKYE, P. A. (2015). Housing for the urban poor: towards alternative financing strategies for low-income housing development in Ghana. International Development Planning Review 37 (4), 446-465 doi.org/l 0.3828/idpr.2015.29

ACHEAMPONG R.A. (20/3), Situational Analysis of Housing in the Greater Kumasi Sub-Region. Study Prepared for the JICA Study Team as Part of the Comprehensive Urban Development Plan for Greater Kumasi Project.

DOI: I0.I3 I40/RG.2.I.334I.I68I Url: http://www.researchgate.net/publication/279961095

ANYANWU, J. C. (2013). Characteristics and macroeconomic determinants of youth employment in Africa. African Development Review, 25(2), 107-129.

ARKU, G. (2009) Housing Policy Changes in Ghana in the 1990s, Housing Studies, 24:2, 26I-272

BECK, U., BONSS, W., \& LAU, C. (2003). The theory of reflexive modernization problematic, hypotheses and research programme. Theory, culture \& society, 20(2), I-33.

BRACKING, S. (2003). The political economy of chronic poverty. Available at SSRN I 754446 http://papers.ssrn.com/sol3/papers.cfm?abstract_id=1754446

BRIGGS, J., AND YEBOAH, I. E. (200I). Structural adjustment and the contemporary subSaharan African city. Area, 33(I), 18-26.

BURGESS, E. W. (1960). Ageing in Western societies. Chicago: University of Chicago Press CALDWELL, J. C. (1966). The Erosion of the Family: A Study of the Fate of the Family in Ghana. Population Studies, 20(I), 5-26.

CASTREE, N. (2010). Neoliberalism and the biophysical environment 2: Theorising the neoliberalisation of nature. Geography Compass, 4(12), I734- 1746.

CIGNO, A. (1993). Intergenerational transfers without altruism: family, market and state. European Journal of Political Economy, 9(4), 505-5I8.

CLARK, G. (1999). Negotiating Asante Family Survival in Kumasi, Ghana. Africa,69(0I), 66-86.

COWGILL, D. O. (1974). Aging and modernization: A revision of the theory. Late life, 123-I45.

COX, D., \& FAFCHAMPS, M. (2007). Extended family and kinship networks: economic insights and evolutionary directions. Handbook of development economics, 4, 37 I I-3784. CREMER, H., KESSLER, D., \& PESTIEAU, P. (1992). Intergenerational transfers within the family. European Economic Review, 36(I), I-I6.

DEVEREUX, S. (200I). Livelihood insecurity and social protection: a re-emerging issue in rural development. Development policy review, 19(4), 507-519.

Fields, G. S. (20I I). Labor market analysis for developing countries. Labour Economics, I8, SI6S22.

FORREST, R. (2013). Housing and family wealth. New York: Routledge.

FOSTER, G. (2000). The capacity of the extended family safety net for orphans in Africa. Psychology, Health \& Medicine, 5(I), 55-62.

GHANA STATISTICAL SERVICE (2012), 2010 Population and Housing Census, National Analytical Report

GIBBON, P. (1993). Social change and economic reform in Africa. Nordiska Afrikainstitutet (Scandinavian Institute of African Studies).

GOODE, WILLIAM J. (1970). World Revolution and Family Patterns. New York: Free Press

GOUGH, K. V., \& KELLETT, P. (200I). Housing consolidation and home-based income generation: evidence from self-help settlements in two Colombian cities. Cities, I8(4), 235-247. GOUGH, K. V., \& YANKSON, P. (20I I). A neglected aspect of the housing market the caretakers of Peri-urban Accra, Ghana. Urban Studies, 48(4), 793-8I0. 
HUAN, C., \& MAHONEY, J. (2002). Equity release mortgages. Housing Finance International, I6(4), 29-35.

HUBERT, F. (2006). The economic theory of housing tenure choice. A Companion to Urban

Economics, Boston: Blackwell Publishing, I45-I58.

JIAFENG W. (2009) Some Reflections on Modernization Theory and Globalization Theory.

Chinese Studies in History, 43:I, 72-98

KONADU-AGYEMANG, K. (200I). Structural adjustment programs and housing affordability in Accra, Ghana. The Canadian Geographer/Le Géographe canadien, 45(4), 528-544.

KORBOE, D. (1992). Family-houses in Ghanaian cities: To be or not to be? Urban Studies, 29(7), II59-II7I.

LALL S., NAVARETTI, G.B., TEITEL, S., AND WIGNARAJA, G., (1994). Technology and enterprise development: Ghana under structural adjustment. New York: St. Martin's Press. LANGEVANG, T. (2008). 'We are managing! 'Uncertain paths to respectable adulthoods in Accra, Ghana. Geoforum, 39(6), 2039-2047.

LANGEVANG, T., AND GOUGH, K. V. (2009). Surviving through movement: the mobility of urban youth in Ghana. Social \& Cultural Geography, 10(7), 74I-756.

LOGAN, J. R., BIAN, F., AND BIAN, Y. (1998). Tradition and change in the urban Chinese family: The case of living arrangements. Social Forces, 76(3), 85 I-882.

MOSER, C. O. N. (1998). The asset vulnerability framework: reassessing urban poverty reduction strategies. World development, 26(I), I-I9.

RHOADS, E. C. (1984). Reevaluation of the aging and modernization theory: The Samoan evidence. The Gerontologist, 24(3), 243-250.

ROTHCHILD, D. (199I). Ghana and structural adjustment: An overview. Ghana: in The Political Economv of Recovery. Rothchild, D. S. (ed.). (199I) L. Rienner Publishers.

SALAMI, C. G. E. (2013). Youth Unemployment in Nigeria: A time for creative intervention. International Journal of Business and Marketing Management, I (2), I8-26

SIMON, D., SPENGEN, W. V., DIXON, C., AND NÄRMAN, A. (I995). Structurally adjusted Africa: poverty, debt and basic needs. Pluto Press.

SINAI, I. (1998). Using the home for income-generation: the case of Kumasi, Ghana. Cities, I5(6), 4I7-427.

TIPPLE, A. G., KORBOE, D. T., AND GARROD, G. D. (1997). A comparison of original owners and inheritors in housing supply and extension in Kumasi, Ghana. Environment and Planning B, 24, 889-902.

Tonkiss, F. (2005). Space, the city and social theory: Social relations and urban forms. Malden, MA: Polity Press.

UN HABITAT (20I I). Ghana Housing Profile. HS Number: HS/I 3 I E, I I. Nairobi, Kenya VERREST, H. (2007). Home-based economic activities and Caribbean urban livelihoods: vulnerability, ambition and impact in Paramaribo and Port of Spain: Amsterdam University Press.

WEBER, R. (2002). Extracting value from the city: neoliberalism and urban redevelopment. Antipode, 34(3), 519-540.

WIRTH, L. (1995) Urbanism as a way of life' in P. Kasinitz, (ed.) Metropolis pp. 58-84. New York: NYU Press

YANKSON, P. W., \& GOUGH, K. V. (20I4). Urban low-income housing in Ghana. In Bredenoord, J., Van Lindert, P. and Smets P. (eds). Affordable Housing in the Urban Global 
South: Seeking Sustainable Solutions. New York: Routledge.

YEBOAH, E. A. (2005). Housing the urban poor in twenty-first century Sub-saharan Africa: policy mismatch and a way forward for Ghana, Geojournal 62: |47-|6| 